УдК 330.88

Ю. О. Журавльова,

к. н. держ. упр., дочент кафедри загальної економічної теорії та економічної політики,

Одеський начіональний економічний університет

ORCID ID: 0000-0003-4794-7691

DOI: $10.32702 / 2306-6814.2019 .11 .86$

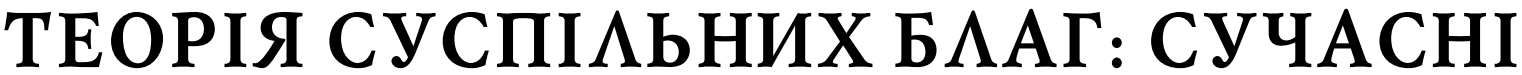 ПІАХОАИ АО ВИЗНАЧЕННЯ СУТНОСТІ
}

Y. Zhuravlova,

$\mathrm{PhD}$ in Public Administration, Associate Professor, Odessa National Economic University

\section{THEORY OF SOCIAL PROTECTION: MODERN APPROACHES TO DETERMINATION} OF SATISFACTION

У статті досліджено сутність теорії суспільних благ та розглянуто погляди вітчизняних зарубіжних науковців стосовно трактування цього поняття. Визначено, що сектор суспільних благ посідає одну із пріоритетних ролей у стратегічному плануванні соціального розвитку держави виконуючи функцію формування соціальної стабільності. Встановлено, що еволюція теорії суспільних благ нерозривно пов'язана з етапами розвитку економічної думки, історія її розвитку також виступає як історія розвитку науки про багатство, добробут та можливі шляхи їх досягнення. Досліджено сутність поняття благо як все, що містить у собі певний позитивний сенс: предмет, явище, продукт праці, що задовольняє певну людську потребу і відповідає інтересам, цілям, спрямуванням індивідуумів. До благ можна віднести природні та суспільні явища, які задовольняють окремі людські потреби, сприяють соціальному прогресу. Досліджено, що найбільшу кількість продукції за вісім років реалізують великі і середні підприємства, але спостерігається негативна тенденція до зменшення долі великих підприємств та позитивна тенденція до збільшення долі малих підприємств. Встановлено, що суспільні блага для населення виступають такими факторами, котрі стримують або ж спряють людському розвитку, створюючи певні стимули чи обмежуючи можливості індивідів і населення в цілому відносно реалізації активної економічної поведінки. В таких умовах надзвичайно важливою виступає ефективність управлінських рішень у ході накопичення благ населення, котра надає змогу оцінювати перспективи підвищення якості людського капіталу, а також забезпечення економічного зростання.

The article explores the essence of the theory of public goods and considers the views of domestic foreign scientists regarding the interpretation of this concept. It is determined that the public goods sector is one of the priority roles in strategic planning of social development of the state, performing the function of forming social stability. It was established that the evolution of the theory of public goods is inextricably linked with the stages of development of economic thought, and the history of its development serves as a history of the development of the science of wealth, welfare and possible ways of achieving them. The essence of the notion of good - as all that contains a certain positive meaning: an object, a phenomenon, a product of labor that satisfies a certain human need and corresponds to the interests, goals, orientation of individuals. Good things include natural and social phenomena that meet individual human needs, promote social progress. It was investigated that the largest number of products sold by large and medium-sized enterprises for eight years, but there is a negative tendency to reduce the share of large enterprises and a positive tendency to increase the share of small enterprises. It has been established that public goods for the population are such factors that restrain or direct human development, creating certain incentives or limiting the capacity 
of individuals and the population as a whole in terms of the implementation of active economic behavior. In such circumstances, the effectiveness of management decisions in the process of accumulation of the benefits of the population, which enables us to assess the prospects for improving the quality of human capital and ensuring economic growth, is of the utmost importance.

The production of public goods serves as an economic activity - the provision of large or small benefits to society - that cannot be effectively carried out by a private enterprise. The private production of social or collective goods is almost impossible, because the benefits of them are thus distributed among the population that is not provides the opportunity to eliminate non-payers from consumption, therefore, any private enterprise or consumer does not have an economic incentive to provide them.

Ключові слова: благо, суспільні блага, теорія, держаßа, регулюВання, ефективність, людські потреби. Key words: good, public goods, theory, state, regulation, efficiency, human needs.

\section{ПОСТАНОВКА ПРОБ $А$ МИ}

Сектор суспільних благ посідає одну із пріоритетних ролей у стратегічному плануванні соціального розвитку держави виконуючи функцію фрормування соціальної стабільності, він забезпечує суспільство як базовими інституційними умовами фрормування людського потенціалу, так і інфраструктурою для розвитку бізнесу. В кризових умовах функціонування постійно виникають питання відносно новітньої економічної теорії формування категоріального апарату з метою детального розуміння складних економічних процесів і явищ. У сучасній економічній, а також політичній літературі відбувається безперервна наукова дискусія відносно формування складових суспільних благ і їх впливу на якісні характеристики суспільства. Теорія суспільних благ є надзвичайно важливою і багатогранною економічною категорією, котра висвітлює сукупність соціально-економічних відносин з питань задоволення різних індивідуальних і суспільних потреб. Оскільки основою життєдіяльності індивідуумів виступає задоволення потреб і надання, або ж споживання певних благ, питання визначення сутності та задоволення соціальних потреб суспільства в сучасних умовах існування держави набуває надзвичайної актуальності та вимагає подальших наукових обгрунтувань.

\section{АНААIЗ ОСТАНHIX АОС IАЖЕНЬ І ПУБ $\Lambda$ ІКАЦЙ}

Наукові дослідження в сорері теорії суспільних благ висвітлюються у наукових працях зарубіжних та вітчизняних науковців таких: Аристотель, Кларк Дж.Б., Стігліц Дж., Эрхард Л., Оганян Г.А., Паламарчук В.О., Румянцев А.П., Мочерний С.В., Ястремський О.І., Будаговська С., Кілієвич О., Луніна І., Чомпа П.

\section{META АОС $\triangle$ IАЖЕНHЯ}

Метою дослідження $\epsilon$ необхідність пошуку та визначення сучасних підходів до трактування сутності теорії суспільних благ, а також визначення стратегічних цілей, котрі притаманні існуючим суспільним благам в Україні. Розвиток теорії в галузі економіки суспільного сектору $\epsilon$ надзвичайно важливим, а також він нерозривно пов'язаний із втручанням держави в сореру надання суспільних благ.

\section{ВИКААА ОСНОВНОГО МАТЕРІААУ}

У сучасних умовах економічного розвитку суспільство переходить від бажання здобувати матеріальні блага для задоволення матеріальних потреб до бажання самовираження, це говорить про те, що потреби сучасної людини безперервно збільшуються. В умовах сьогодення спостерігається перехід від необхідності задоволення фізіологічних потреб до естетичних і духовних, що свідчить про зміни в системі цінностей суспільства. Перехід від перманентних до вищих потреб $\epsilon$ результатом трансорормації свідомості членів суспільства, що вимагає розробки новітнього підходу до вивчення процесів та явищ, зокрема економічних, бо традиційний науковий підхід не може пояснити закономірностей розвитку інтелектуального суспільства.

Еволюція теорії суспільних благ нерозривно пов'язана з етапами розвитку економічної думки, історія ії розвитку також виступає як історія розвитку науки про багатство, добробут та можливі шляхи їх досягнення. Проблематика теорій суспіль них благ цікавила відомих мислителів та фрілософрів.

Економіка і техніка виступає засобом, а людина, його матеріальне, фрізичне, моральне благополуччя основними соціальними індикаторами прогресивності або регресивності проведеної політики.

Так, Аристотель наголошував на тому, що: "багатство - це, звичайно, не те благо, якого ми прагнемо, оскільки воно корисне, тобто існує тільки заради чогось іншого" [1].

Розглянемо сутність поняття "благо" за визначенням Кларка Дж.Б.: "благо - це все, що містить у собі певний позитивний сенс: предмет, явище, продукт праці, що задовольняє певну людську потребу і відповідає інтересам, цілям, спрямуванням індивідуумів. До благ можна віднести природні та суспільні явища, які задовольняють окремі людські потреби, сприяють соціальному прогресу. Кожне благо, яке корисне одному інди- 
відууму буде корисне і іншому і не має якості, які спонукають індивідуума, піти на деяку жертву, щоб їх отримати" [2].

Дж.Е. Стігліц ключовими характерними особливостями суспільних благ називає: "по-перше - нормування користування ними є реальним; по-друге - нормування користування ними $є$ небажаним" [3]. Аналізуючи вищенаведене, наголосимо на тому, що всі ми цінуємо користь від отримання благ суспільного споживання, проте оскільки кожен окремо вважає, що він отримує вигоду від блага незалежно від того, оплачує він ці блага чи ні, у індивіда немає стимулу платити за них добровільно.

На практиці впровадження теорії суспільних благ відбулося в післявоєнній Німеччині за рахунок здійснення економічної рефрорми Людвіга Ерхарда. Згідно з запропонованою ним неоліберальною концепцією розвиток суспільних благ має забезпечуватися за рахунок складових наведених на рисунку 1.

Отже, аналізуючи вищенаведене наголосимо на тому, що відповідно до концептуальних підходів Л. Ерхарда, основою регулювання економічних відносин повинне виступати забезпечення неможливості обмеження конкуренції різних фрорм господарювання із монополістичними, олігархічними або ж іншими організаційно-економічними структурами, котрі за рахунок своєї переваги можуть здійснювати вплив на процес розвитку "досконалого конкурентного середовища". Водночас "досконале конкурентне середовище" виступає підгрунтям розвитку соціальної економіки та, відповідно до висновків послідовників неокласичної економічної школи, свідчить про таку ситуацію на ринку, коли існує велика кількість продавців та покупців тотожного товарного продукту, а саме майже однорідного продукту із однаковими споживчими властивостями [5].

Суспільні блага для населення виступають такими фракторами, котрі стримують або ж спряють людському розвитку, створюючи певні стимули чи обмежуючи можливості індивідів і населення в цілому відносно реалізації активної економічної поведінки. В таких умовах надзвичайно важливою виступає ефрективність управлінських рішень у ході накопичення благ населення, котра надає змогу оцінювати перспективи підвищення якості людського капіталу, а також забезпечення економічного зростання.

У відповідності до своїх внутрішніх властивостей суспільні блага взаємопов'язані. Приналежність критеріїв в їх крайніх випадках, таких як конкурентоспроможність і не виключність, дають змогу провести межу між чистими і суспільними благами. Чисте суспільне благо це неконкурентоспроможність та не виключність, вони колективно споживаються, а приватному благу - конкурентоспроможність і виключність. У контексті реального життя чисті приватні суспільні блага можна представити як два різних полюси шкали економічних благ, між якими знаходяться різноманітні змішані блага.

Якщо взяти до уваги той фракт, що чисельність споживачів суспільних благ надзвичайно висока, а отриман-

ня плати за їх надання надзвичайно ускладнене, то, ймовірно, одним правильним і дієвим виробником суспільних благ може бути лише держава. Проте, стосовно цього питання серед вчених до тепер відкрита дискусія відносно ролі держави в наданні населенню суспільних благ.

Дж.С. Мілль пояснював суспільне благо з такої точки зору: "такий підхід, за якого податки, які сплачуються кожним членом суспільства, розглядаються як відшкодування за послуги, що одержані від суспільства" [6].

Пояснюючи сутність суспільного капіталу С. Мочерний, Я. Ларіна, С. Юрій наголосили на тому, що характерним виступає намагання визначити головні чинники виробництва суспільних благ та ролі держави [6].

Такі українські науковці як С. Будаговська, О. Гриценко, О. Длугопольський, Л. Краснікова, І. Луніна, І. Малий, О. Ястремський [7], трактуючи френомен суспільних благ, досліджують їх на основі балансу доходів індивідуумів і розподілу між приватними і суспільними на основі попиту та пропозиції. О. Ястремський та О. Гриценко аналізували поведінку двох індивідуумів, через фріксацію параметрів споживчої поведінки обгрунтували принцип отримання суспільного блага і необхідну умову розподілу ефективності за Парето [7].

Зміни, що відбуваються у світовій економіці, становлення інформаційного суспільства та інноваційної економіки вимагають уточнення поняття "Суспільне благо". Сьогодні суспільні блага, на наш погляд, потрібно визначати в більш широкому сенсі, а саме: як блага представлені товарами і послугами, виробленими в різних секторах економіки для задоволення суспільних (колективних) потреб. Те твердження грунтується на тому, що вітчизняні вчені, як правило, пов'язують виробництво суспільних благ тільки в державному секторі. Це правильно, але тільки відносно чистих суспільних благ для яких властиві невиключність і неконкурентність у споживанні. Прикладами чистих благ є національна оборона, безпека, законодавство та ін.

Суспільними благами також називають ті блага, котрі ми отримуємо безкоштовно, отже, ті, за використання яких споживачі не платять. Такі суспільні блага відповідають двом ознакам: виключність блага; благо 
як об'єкт суперництва. Виключно приватні блага є об'єктом суперництва. Більшість циркулюючих в економіці благ - приватні [8].

Аналізуючи внесок українських вчених у розвиток теорії суспільних благ наголосимо на твердженні П. Чомпа стосовно сутності категорії "благо", котру він трактував як фундамент для задоволення людських потреб. Він виступав прихильником теорії цінності і на його думку "існування блага без вартості $\epsilon$ неприпустимим; коли також повітря, вода, водоспад, музей не мають ринкової вартості, незважаючи на те, вони $є$ благами, які служать для задоволення наших потреб" [9].

У теорії економічної думки існують визначені типи благу залежності від можливостей оцінки їх якості споживачами, це грунтується на доступності інфрормації про якість споживачеві. Виокремлюють досліджувані блага, досвідчені блага та довірчі блага. Досліджувані блага - виступають таким видом благ, для яких відносні витрати оцінки якості до початку процесу споживання невеликі. Досвідчені блага - такий вид благ, для котрих відносні витрати оцінки якості. Невиключеність та неконкурентність суспільність благ призведе до такої ситуації, що їх виробництво не може бути організовано на ринкових засадах.

Виробництво суспільних благ виступає як економічна діяльність - надання великих або ж малих вигод суспільству - котрі не можуть ефективно здійснюватися приватним підприємством, приватне виробництво суспільних чи колективних благ майже $є$ неможливе, за рахунок того, що вигоди від них таким чином розподіляються серед населення, що не надає можливості усунути неплатників від споживання, отже будь-яке окреме приватне підприємство або споживач не мають економічного стимулу в їх наданні. Також вважаємо необхідним виокремити такі положення стосовно особливостей суспільних благ:

- суспільні блага - це блага представлені товарами і послугами, виробленими в різних секторах економіки для задоволення колективних потреб;

- джерелом виробництва суспільних благ виступають фрінансові ресурси держави, що фрормуються за рахунок податкових відрахувань фрізичних та юридичних осіб;

- виробництво і продаж окремих видів суспільних благ може здійснюватися в приватному секторі економіки і реалізовуватися через ринковий механізм.

\section{ВИСНОВКИ}

Отже, підводячи підсумки проведеного дослідження вважаємо необхідним наголосити на тому, що наведені вище дослідження сутності поняття "суспільні блага" з точки зору різних науковців виступають методологічним підгрунтям, котре дає можливість розкрити категоріальну сутність суспільних благ. Особлива природа суспільних благ грунтується на тому, що їх споживання може бути тільки спільним і рівним: чим більше дістається одному домогосподарству, тим більше, а не менше дістається будь-якого іншого. Ми вважаємо, доцільним здійснювати синтез досліджених наукових підходів до визначення сутності поняття "суспільні блага", що дасть змогу більш детально та точно дослідити сутність суспільних благ і виявити особливості їх відтворення. Питання визначення сутності поняття "суспільні блага" залишається надзвичайно актуальним та до кінця не дослідженим, саме тому це питання потребує подальших наукових досліджень.

\section{Література:}

1. Аристотель. Никомахова этика / Аристотель // Сочинения: в 4-х т.; пер. И.В. Брагинской. - М.: Мысль, 1983. $-830 \mathrm{c}$.

2. Кларк Дж. Б. Распределение богатства: Пер. с англ. - М.: Гелиос АРВ, 2000. -367 с.

3. Stiglitzs J.E. Rethinking macroeconomics: What Failed, and How to Repair It / J. E. Stiglitzs / / Journal of the European Economic Association. - 2011. - Vol. 9 (4). - P. 591-645.

4. Эрхард Л. Благосостояние для всех / Л. Эрхард. М.: Начала-Пресс, 1991. - 336 с.

5. Політична економія: навч. посіб. / Г.А. Оганян, В.О. Паламарчук, А. П. Румянцев та ін.; За заг. ред. Г.А. Оганяна. - К.: МАУП, 2003. - 520 с.

6. Економічна енциклопедія:у 3-хт. / [під ред. С.В. Мочерного]. - К.: Видав. центр"Академія", 2000. - Т. 2. $848 \mathrm{c}$.

7. Ястремський О.І. Основи мікроекономіки / О.І. Ястремський, О.Г. Гриценко. - К.: "Знання", КОО, 1998. - $714 \mathrm{c}$.

8. Мікроекономіка і макроекономіка: підручник / С. Будаговська, О. Кілієвич, І. Луніна та ін.; за заг. ред. С. Будаговської. - К.: Вид-во Соломії Павличко "Основи", 2003. - 517 с.

9. Чомпа П. Нариси економетрії / П. Чомпа // Українська економічна думка: хрестоматія / упоряд. С.М. Злупко. - К.: Знання, 2007. - С. 519-528.

\section{References:}

1. Aristotel' (1983), Nikomahova jetika [Nicomache ethics], Sochinenija, Moscow, Russia.

2. Klark, Dzh. B. (2000), Raspredelenie bogatstva [Wealth distribution], Gelios ARV, Moscow, Russia.

3. Stiglitzs, J. E. (2011), "Rethinking macroeconomics: What Failed, and How to Repair It", Journal of the European Economic Association, vol. 9 (4), pp. 591-645.

4. Jerhard, L. (1991), Blagosostojanie dlja vseh [Welfare for all], Nachala-Press, Moscow, Russia.

5. Ohanian, H.A., Palamarchuk, V.O. and Rumiantsev, A.P. (2003), Politychna ekonomiia [Political Economy], MAUP, Kyiv, Ukraine.

6. Mochernyj, S.V. (2000), Ekonomichna entsyklopediia [Economic Encyclopedia], Vydav. tsentr "Akademiia", Kyiv, Ukraine.

7. Yastrems'kyj, O.I. and Hrytsenko, O.H. (1998), Osnovy mikroekonomiky [Basics of microeconomics], Znannia, Kyiv, Ukraine.

8. Budahovs'ka, S. Kiliievych, O. and Lunina, I. (2003), Mikroekonomika i makroekonomika [Microeconomics and macroeconomics], Vyd-vo Solomii Pavlychko "Osnovy", Kyiv, Ukraine.

9. Zlupko, S.M. (2007), Ukrains'ka ekonomichna dumka: khrestomatiia [Ukrainian economic thought: textbook], Znannia, Kyiv, Ukraine.

Стаття надійшла до редакцї̈ 23.05.2019 p. 